\title{
Do Women On Boards And In Top Management Reduce Earnings Management? Evidence In France
}

Faten Lakhal, IRG, University of Paris-Est, France \& University of Sousse, Tunisia

Amal Aguir, ISG, University of Sousse, Tunisia

Nadia Lakhal, ISG, University of Sousse, Tunisia

Adnane Malek, ISCAE, University of Manouba, Tunisia

\begin{abstract}
The purpose of this paper is to examine the effect of gender diversity on the boardroom and in top management positions on earnings management by French-listed firms. Based on a sample of 170 firms over 4 years, we find that the proportion of women on the board standing as a director or a chair reduces earnings management. This finding suggests that women are effective on their monitoring role and are then considered as a crucial corporate governance device. We also find that the relationship between the presence of at least three women on the board and earnings management is negative suggesting that by increasing the number of women on board through regulation and legislation, French firms are likely to enhance the effectiveness of the board to better detect earnings management. However, women standing in CEO and CFO positions do not affect earnings management practices. These findings suggest that efforts made by political bodies to promote equality between men and women on boards are beneficial for French-listed companies by limiting earnings management practices. However, regulating or imposing a quota of women on boards can create a temporal shortage of qualified women available to take up such positions.
\end{abstract}

Keywords: Gender Diversity; Earnings Management; Top Management; CEO; CFO

\section{INTRODUCTION}

ender diversity in top corporate positions has received growing attention in the last decade subsequently to legislative reforms and financial scandals and crisis. Since, researchers have focused on the pattern of appointing women as directors on the board or as executives. Differences in the representation of women on boards have been found across countries. Numerous studies have examined the relationship between women appointment on boards and firm performance, namely McKinsey\&Company (2007) in an international level, Carter et al. (2003), Farrel and Hersch (2005) in the Unites States, Ruigrok et al. (2007) in Switzerland, Campbell and Minguez-Vera (2008) in Spain and Ahern and Ditmar (2010) in Norway.

The ongoing literature has shown that women are less likely to act similarly to independent directors (Adams, 2008); are likely to check on CEOs decisions tougher than men (Valenti, 2008), are considered an attribute of good governance (Merridee et al. 2010 and Rose, 2007); and are inclined to improve the quality of board decisions (Dallas, 2002). Another stream of literature has concluded on the effect of gender diversity on board effectiveness in terms of its monitoring role and the quality of its decisions (Valenti, 2008; Adams and Ferreira, 2009 and Nielson and Huse, 2010).

The relationship between gender diversity and earnings quality is a recent issue (Ye et al. 2010, Krishnan and Parsons, 2008, Barua et al. 2010, Peni and Vahamaa, 2010, and Gul et al. 2011). The results of these studies are inconclusive and rely on one feature of gender diversity. We extend this literature to examine the effect of gender 
diversity, both in top management positions and boards, on earnings management in the French context. By so doing, we test whether the board becomes more efficient in his monitoring role regarding earnings quality as the representation of women on board increases. Moreover, we aim at exploring whether women in top management positions are involved with earnings management practices as theses positions have major influence among earnings determination process.

To date, most studies that have analyzed the relationship between gender diversity and earnings quality were carried out in a voluntary context of appointing women on boards (Gul et al. 2011; Zuobao and Xie, 2010). Our research compliments these studies by focusing on the effect of board gender diversity in a regulated environment. Indeed, France has moved in 2010 from a voluntary setting to a setting where firms are strongly pressured by regulation to appoint more women on boards. Regulating the promotion of women on boards could have an effect on the propensity of detecting earnings management on board meetings.

Several countries around the world have taken initiatives to reach a predetermined level of women participation on boards. Norway was the first country to adopt a coercive approach consisting of a $40 \%$ quota of women to be represented on boards with a deadline of January 2008. This regulatory initiative was followed by Spain, Belgium, the Netherlands, and Sweden which are considering a similar type of legislation. France has also adopted the law of Zimmerman/cope in January 2011 to compel firms to introduce a quota of women on boards of $40 \%$ for publicly traded companies that must have at least $20 \%$ WoB by January 2014 and full compliance by January 2017. Currently, France is following a "comply or explain" rule since 2010 to encourage firms to enhance the level of women on boards. This rule is included by the AMF to the French corporate governance code. Under such an enabling approach, firms follow a system of voluntary compliance with codes of governance, but with mandatory disclosure of compliance or non-compliance.

The purpose of this paper is to examine the relationship between the presence of women in top management positions (i.e. CEO, CFO and chair of the board) and on boards and earnings management in the French case. Our results show that there is a negative relationship between the proportion of women on the board standing as a director or a chair and earnings management. This finding suggests that women are effective in their monitoring role and have more ethical behavior comparatively with men. As a chair, female chair is more likely to detect earnings manipulation to avoid litigation risk and loss of reputation as they do not easily access to such positions. However, Women CFO and CEOs do not significantly influence earnings management practices. We also find that the relationship between the presence of at least three women on the board and earnings management is negative suggesting that the existence of a threshold of three or more women on the board can enhance the effectiveness of the board to better detect earnings management.

The remainder of our article is organized as follows. Next section examines the link between gender diversity and earnings management. Section 3 presents data variables and model followed by results and discussion. Last section concludes the paper.

\section{LITERATURE REVIEW AND HYPOTHESES DEVELOPMENT}

\subsection{Women On Boards And Earnings Management}

Board diversity is supported by the agency theory (Jensen and Meckling, 1976). Gender diversity reduces conflicts of interest between managers and shareholders. Indeed, diversity ensures the independence of the board, can provide the firm with new ideas and perspectives based on innovation and creativity and also helps make the most effective decisions (Fondas and Sassalos, 2000; Huse and Solberg, 2006). Moreover, diversity prevents an individual or a group of people to dominate decision-making process and thus reduce agency problems. Carter et al. (2003) suggest that a more diverse board can be considered a better controlling mechanism for managers because diversity is likely to enhance the independence of the board. The current literature also suggests that female directors provide greater supervision and monitoring actions reducing agency costs and aligning managers' interests with those of shareholders. Daily et al. (1999) and Adams and Ferreira (2009) argue that women directors actively attend board meetings. This helps strengthen the supervision of the board. 
In the empirical literature, the only study by Gul et al. (2011) examines the effect of women directors on earnings quality in a voluntary environment of appointing women on boards. These authors show that US firms with board gender diversity have a better quality of their earnings and are less likely to manage earnings.

Based on agency theory predictions, women directors are considered as a corporate governance device related to board composition. Board gender diversity improves the monitoring of managers and could lead to more earnings management detection. The preceding discussion leads to the following hypothesis:

$\mathbf{H}_{1}$ : There is a negative relationship between board gender diversity and earnings management.

According to the critical mass theory (Kramer et al. 2006), the impact of women on the board becomes more pronounced when their number reaches a certain threshold, or a critical mass. This theory can be traced to Granovetter (1978) who argues that a slight shift in the heterogeneity of a group can result in a large shift in the group's overall behavior. Kramer et al. (2006) find that "women bring a collaborative leadership style that benefits boardroom dynamics by increasing the amount of listening, social support, and win-win problem solving".

Konrad et al. (2008) argue that the presence of at least three women on boards is likely to bring real change into the board. According to Adams and Ferreira (2009), the relevant measure of gender diversity should not be whether there is a woman director who sits on the board, but rather whether there are enough women directors (three or more) to ensure that they are likely to speak and act freely and perform their monitoring roles effectively including the detection of earnings management practices. Luckerath-Rovers (2010) shows that appointing at least three women on boards may lead to better decision-taking. With more women on boards, the board becomes more dynamic and collaborative, and women feel free to discuss their opinions and socialize in a mixed group.

Based on the contributions of the critical mass theory, the existence of three women at least on boards is likely to enhance the effectiveness of gender diversity mechanism and reduces then earnings management practices. Accordingly, our second hypothesis is as follows:

H2: There is a negative relationship between the presence of at least three women on boards and earnings management.

\subsection{Women In Top Management And Earnings Management}

In sociology, Ford and Richardson (1994) examine the thirteen studies that consider gender as a factor in ethical decision making. The authors find that eight of these studies support the claim that women are more likely to adopt ethical behavior than men. Betz et al. (1989) show that men are more likely than women to undertake illegal activities, such as, insider trading. Hence, as earnings management is an illegal practice, Healy and Wahlen (1999) and Roychowdhury (2006) suggest that such a practice is considered unethical since it intentionally misleads shareholders about firm performance. Previous studies provide evidence on the link between male and their propensity for illegal activities.

Using a large sample of Chinese listed firms from 2001 to 2006, Ye et al. (2010) find no significant relationship between women in top management and earnings management suggesting that there are no ethical value differences between men and women in China. This is particularly due to the spread of socialist egalitarian ideology since the founding of communist China in 1949. Schminke et al. (2002) examine how different leadership styles may affect individual and group ethical decisions. They find that more active leadership leads to greater conformity in ethical decision. Krishnan and Parsons (2008) examine the relationship between the proportion of women senior managers and earnings quality. Based on a sample of 770 US firms from 1996 to 2000, the authors find that gender diversity in senior management improves the quality of reported earnings by reducing earnings smoothing and loss avoidance.

In addition to ethical differences, the psychology literature based on gender suggests that men and women are different in many aspects, and their characteristics may also influence their behaviour in the workplace. For instance, it was reported that women are more inclined to be cautious and risk averse than men (Powell and Ansic, 
1997). Moreover, the existing literature has documented a positive association between earnings management and litigation risk and loss of reputation (Ducharme et al. 2004; Hunton et al. 2006). In a meta-analysis of 150 studies on risk-taking behaviors, Byrnes et al. (1999) find that on average men are more likely to take risks than women in strategic positions. Hence, women are likely to have greater aversion to earnings management than their male counterparts. Indeed, women are less likely to be exposed to potential litigation and loss of reputation risks.

Several studies show that there is a considerable influence of CFOs on earnings management activities. In a recent study, Jiang, Petroni and Wang (2010) compare CFOs and CEOs in earnings management activities. The authors find that CFOs have more influence than CEOs in earnings management decisions. Peni and Vähämaa (2010) also suggest that CFOs are executives with the most influence on company's outcome.

Given psychological differences between the sexes, female CFOs may be inherently more likely to avoid earnings manipulation. Based on a sample of 1,559 (1,222) US firms in 2005, Barua et al. (2010) show that companies with female CFOs have lower discretionary accruals than their male counterparts. The authors argue that females are more cautious and less aggressive in a variety of business and finance settings.

As CFOs, CEOs are likely to influence governance practices and company's reports. Women on these positions should exert a positive influence on corporate governance, as they are inclined to be more ethical, are more risk averse and are more conservative than men.

To sum up, women in top positions are likely to exert a positive influence on earnings quality leading them to avoid earnings management practices. The preceding discussion leads to the following hypothesis:

H4: There is a negative relationship between top management gender diversity and earnings management.

\section{DATA AND METHODOLOGY}

\subsection{Data}

Our sample includes French firms listed on the CACALL shares index from 2008 to 2011. We exclude financial companies since their atypical behaviour in financial reporting. Our final sample includes 170 companies over 4 years. Data related to corporate governance and ownership structure were hand-collected from annual reports downloaded from the AMF (Autorités des Marchés Financiers) website. Financial data were gathered from the Thomson One Banker database.

\subsection{Variable Measurements}

\subsubsection{Earnings Management}

According to Schipper (1989), earnings management is a deliberate action by managers in the process of financial information presentation in order to gain private benefits. Managers exercise their discretion over accounting numbers and use accounting choices to manipulate earnings for opportunistic purposes. The common literature relies on discretionary accruals to detect such a practice. We then measure earnings management by discretionary accruals estimated using the models of Dechow et al. (1995), Kothari et al. (2005) and Raman et Shahrur (2008) to enhance the robustness of our results.

- $\quad$ Jones-modified model (1995)

TAi, $/ \mathrm{Ai}, \mathrm{t} 1=0(1 / \mathrm{Ai}, \mathrm{t} 1)+1[(\mathrm{CAi}, \mathrm{t} \quad \mathrm{CCRi}, \mathrm{t}) / \mathrm{Ai}, \mathrm{t}$ 1] $+2(\mathrm{PPEi}, \mathrm{t} / \mathrm{Ai}, \mathrm{t} \quad 1)+\mathrm{i}, \mathrm{t}$

With: TAi, t: Total accrual in year $\mathrm{t} ; \mathrm{Ai}, \mathrm{t}-1$ : Total assets in year $\mathrm{t}-1 ; \Delta \mathrm{CAi}, \mathrm{t}$ : Change in sales; $\triangle \mathrm{CCRi}, \mathrm{t}$ : change in receivables; PPEi, t: Gross proprety plant and equipement; $\varepsilon \mathrm{i}, \mathrm{t}$ : Residuals that represent the estimation of discretionary accruals. 
- $\quad$ Kothari et al. (2005) model

TAi,t/Ai,t-1= 0(1/Ai,t 1)+1[ CAi,t CCRi,t)/Ai,t 1+2(PPEi,t/ Ai,t 1)+3(ROAi,t 1+ i,t

With: ROAi, t: Return on assets.

- $\quad$ Raman and Shahrur (2008) model

$\mathrm{TAi}, \mathrm{t} / \mathrm{Ai}, \mathrm{t} \quad 1=0(1 / \mathrm{Ai}, \mathrm{t} \quad 1)+1[(\mathrm{CAi}, \mathrm{t} \quad \mathrm{CCRi}, \mathrm{t}) / \mathrm{Ai}, \mathrm{t} \quad 1]+2(\mathrm{PPEi}, \mathrm{t} / \mathrm{Ai}, \mathrm{t} \quad 1)+3(\mathrm{ROAi}, \mathrm{t} 1$

$+4(\mathrm{MTBi}, \mathrm{t})+\mathrm{i}, \mathrm{t}$

With: MTBi, t: The market to book ratio.

\subsubsection{Gender Diversity Variables}

We measure gender diversity on board and in top management using the 5 following variables:

- $\quad$ The percentage of women on board (Women) measured by the number of women on board to the total number of members on board.

- $\quad$ A binary variable (3Women) coded as 1 if there are at least 3 women on the board and 0 otherwise.

- A binary variable (WomCEO) coded as 1 if there is a woman standing at the CEO position and 0 otherwise.

- A binary variable (WomCFO) coded as 1 if there is a woman standing at the CFO position and 0 otherwise.

- A binary variable (WomChair) coded as 1 if a woman is the chair of the board and 0 otherwise.

\subsubsection{Control Variables}

As gender diversity is not the only determinant for earnings management, we add control variables in our regression models. The extant literature has shown the existence of a relationship between earnings management and firm size (Bozec (2008) and Yang et al. (2008)), Board size (Beasley (1996) and Firth et al. (2007)), Board independence (Jeanjean (2000), CEO duality (Peasnell et al. 2000 and Dechow et al. 1996), Ownership dispersion: (Jensen and Meckling, 1976), Performance: Kasznik (1999) and Haw et al. (2004), Growth opportunities: Chen and Chung (2002) and Chen et al. (2010) Leverage: (Jensen, 1986) 
Table 1. Variable Definition

\begin{tabular}{|c|c|c|}
\hline Variable & Definition & Measure \\
\hline \multicolumn{3}{|l|}{ Dependent variable } \\
\hline DA 1 & $\begin{array}{l}\text { Discretionary accruals using Jones modified } \\
\text { (1995) model }\end{array}$ & $\begin{array}{l}\text { Absolute value of residuals estimated using } \\
\text { Jones modified (1995) model. }\end{array}$ \\
\hline DA 2 & $\begin{array}{l}\text { Discretionary accruals using Kothari et al. } \\
(2005) \text {. }\end{array}$ & $\begin{array}{l}\text { Absolute value of residuals estimated using } \\
\text { Kothari et al. (2005). }\end{array}$ \\
\hline DA 3 & $\begin{array}{l}\text { Discretionary accruals using Raman and } \\
\text { Shahrur (2008). }\end{array}$ & $\begin{array}{l}\text { Absolute value of residuals estimated using } \\
\text { and Shahrur (2008). }\end{array}$ \\
\hline \multicolumn{3}{|c|}{ Independent variables } \\
\hline Women & The proportion of women on the boardroom. & $\begin{array}{l}\text { Number of women directors to total board } \\
\text { members. }\end{array}$ \\
\hline WomCEO & A Woman stands at the CEO position & $\begin{array}{l}\text { A dummy variable that equals to } 1 \text { if the } \\
\text { CEO is a woman and to } 0 \text { otherwise. }\end{array}$ \\
\hline WomChair & A Woman chair. & $\begin{array}{l}\text { A dummy variable that equals to } 1 \text { if the } \\
\text { chair is a woman and to } 0 \text { otherwise. }\end{array}$ \\
\hline WomCFO & A woman stands for the CFO position & $\begin{array}{l}\text { A dummy variable that equals to } 1 \text { if the } \\
\text { CFO is a woman and to } 0 \text { otherwise. }\end{array}$ \\
\hline 3 Women & At least three women on the board & $\begin{array}{l}\text { A dummy variable that equals to } 1 \text { if there } \\
\text { are at least three women on the board and to } \\
0 \text { otherwise. }\end{array}$ \\
\hline \multicolumn{3}{|l|}{ Control variables } \\
\hline Boardsize & Board Size & Total number of board members. \\
\hline Duality & Board duality & $\begin{array}{l}\text { A dummy variable that equals to } 1 \text { if the } \\
\text { chair is also the CEO of the firm and to } 0 \\
\text { otherwise. }\end{array}$ \\
\hline Indep & Board independence & The proportion of independent directors. \\
\hline Lev & Leverage & The ratio of total debt to total assets. \\
\hline FSize & Firm size & The natural logarithm of total assets. \\
\hline $\mathrm{ROA}$ & Return on assets & The ratio of net income to total assets. \\
\hline MBR & Market to book ratio & The ratio of market value to book value. \\
\hline Float & Ownership dispersion & The percentage of shares held by the public. \\
\hline
\end{tabular}

\subsection{The Models}

We use a panel regression analysis for a sample of 170 firms listed on the French CACALL index for four years (2008-2011). Our model is as follows:

$\mathrm{DA}=\alpha 1+\alpha 2$ (Women) $+\alpha 3$ (3Women) $+\alpha 4$ (WomChair) $+\alpha 5$ (WomCEO) $+\alpha 6$ (WomCFO) $+\alpha 7$ (Bsize) + $\alpha 8$ (Indep) $+\alpha 9$ (Duality) $+\alpha 10$ (Lev) $+\alpha 11($ ROA $)+\alpha 12$ (MBR) $+\alpha 13$ (Fsize) $+\alpha 14$ (float) $+\varepsilon$

With:

DA: discretionary accruals estimated using three models: Jones modified (1995), Kothari et al. (2005) and Raman and Shahrur (2008).

\section{RESULTS AND DISCUSSION}

\subsection{Descriptive Analysis}

Table 2 shows that the dependent variable, measured by the absolute value of discretionary accruals displays a level of 0.892 according to the Jones-modified model (1995). This is comparable to the level achieved by Kothari et al. (2005) model which establishes a level of 0.469 and that obtained by applying the model of Raman and Shahrur (2008) which also reached a level of 0.484.

Panel A of Table 2 also shows that the average percentage of women in the board is $12.69 \%$. This proportion is low compared to that recorded by Norway and other European countries, which have witnessed 
increased pressure for more women on boards from market forces. According to catalyst (2011) report, the proportion of women appointed to boards in Norway went from $28.2 \%$ to $39.7 \%$ because of legislation adopted in 2006. Norway has then the highest proportion of women appointed as board directors. The percentage of seats held by women in Sweden, 25.5\%, and Finland, 20.9\%, increased to $27.3 \%$ and $24.5 \%$, respectively. This increase is concurrent with Sweden's and Finland's adoption of regulation in 2007 and 2008, respectively. Countries such as Canada and the United States, where there was no government intervention during or before 2009, exhibit lower averages of about 13\% (Catalyst, 2011). France has only adopted an enabling approach in 2010. An increase in the number of women as board member can be then expected in the coming years.

The board is composed of 6 members on average. Among these members, $42.8 \%$ on average are independent. Finally, the percentage of shares held by public is $43.5 \%$. This shows that the French listed companies have a relatively concentrated ownership structure.

Regarding top management positions, panel B of Table 2 shows that the positions of CEO and chairman of the board of directors or chief financial officer, we notice a minimal presence of women $7.8 \%$ respectively, $5.7 \%$, $6.3 \%$ of the observations. We can conclude that women are still absent in top management positions. The marginal presence of women in top management positions can be justified by the glass ceiling phenomenon preventing women's access to the highest positions in the hierarchy. It seems that family tasks unequally distributed make it hard for women to access to these key positions in the company. Table 2 also shows that $10 \%$ of our sampled firms have at least 3 women on the boardroom suggesting that even if French companies move to the enabling approach by complying with the recommendations of the Corporate Governance Code, the number of women on board remains limited.

Table 2. Descriptive Statistics

\begin{tabular}{lcccc}
\hline \multicolumn{1}{c}{ Panel A } & Mean & Std Deviation & Min & Max \\
\hline DA1 & 0.892 & 5.927 & 0 & 120.22 \\
DA 2 & 0.469 & 2.862 & 0 & 64.706 \\
DA 3 & 0.484 & 2.867 & 0 & 64.624 \\
Women & 0.126 & 0.123 & 0 & 0.75 \\
Indep & 0.428 & 0.233 & 0 & 0.75 \\
Bsize & 11.33 & 2.889 & 4 & 22 \\
FSize & 6.723 & 2.345 & 2.149 & 12.508 \\
ROA & -0.613 & 4.82 & -10.166 & 4.353 \\
MTB & 2.748 & 4.251 & -3.41 & 0.168 \\
Lev & 0.226 & 0.215 & 0 & 0.999 \\
Float & 0.435 & 0.195 & 0 & \\
\hline \multicolumn{1}{c}{ Panel B } & Number & Frequency & & \\
\hline 3Women & 68 & 0.10 & & \\
WomChair & 39 & 0.057 & & \\
WomCEO & 53 & 0.078 & & \\
WomCFO & 43 & 0.063 & & \\
Duality & 465 & 0.684 & & \\
\hline
\end{tabular}

\subsection{Mulrivariate Analysis}

Table 3 presents the results of panel regressions of gender diversity on earnings management. The proportion of women in the board has a negative and significant effect on earnings management. This finding confirms our first hypothesis and supports agency theory and sociology predictions. Hence, women positively affect the effectiveness of board monitoring leading to more earnings management detection (Adams and Ferreira, 2009). They are considered as effective controllers compared to men because they provide greater oversight for management reports and provide great attention to detail. Moreover, women have a higher level of ethical values than men (Krishnan and Parsons, 2008). They can also improve decision-making, behavior and the effectiveness of the board. It is also noteworthy that most diverse boards improve not only their monitoring ability but also the quality of their decisions. Ultimately, the presence of women on board is a crucial corporate governance device to prevent such practices and reduce agency costs. 
The negative relationship between board gender diversity and earnings management is similar to that found by Gul et al. (2011) in a context where market forces determine the number of women on boards. In Such a context, firms select their board members voluntarily to maximize shareholder's value (Duchin et al. 2010). This leads to better earnings quality and then reduces earnings management practices. We show that this result holds in a context where firms are pressured by regulation to appoint more women on their boards. In the French case and since 2010, corporate governance regulation is deemed to increase the number of women on boards and then increase the monitoring role of the board. Indeed, under the Bebchuk-Fried (2005) managerial power hypothesis, regulating the number of female directors, i.e. requiring firms to comply or explain, would enhance board monitoring by reducing the influence of the CEO and top management over its composition. This reduction in the power of management to perpetuate the old boys' club mentality is compatible with the idea of women on boards being better "watchdogs" and then an effective corporate governance device.

Table 3 also shows that the presence of women as a chair of the board negatively and significantly affects earnings management. This result coincides with those found by Klenke (2003) and Peni (2011). This finding suggests that women have different ways in the exercise of power. Indeed, women show a greater concern for interpersonal relationships and the use of rules of fairness in powerful positions than men. Similarly, prior research finds that men and women differ in their characteristics and behaviors and show that women have a higher level of ethical awareness than men. Women are not only more cautious than men, but they are less prone to opportunism in their decision-making. This shows the magnitude of the position of woman as a chair of the board as well as its power and responsibility. Finally, female chair may be inherently more likely to detect earnings manipulation to avoid litigation risk and loss of reputation as they do not easily access to such positions.

The relationship between female $\mathrm{CFO}$ and $\mathrm{CEO}$ and earnings management is negative as expected but not significant using three models to estimate discretionary accruals. These results are similar to those found by Ye et al. (2010) in the Chinese context. This finding suggests that the glass ceiling phenomenon prevents women from accessing to such positions in France. These positions are indeed men dominated positions.

Among control variables, five are significant. First we show a positive and significant relationship at the 1 $\%$ level between firm size and earnings management. The results in Table 3 also show that companies with an independent board are less inclined to engage in earnings management practices. This relationship is negative and significant at the 5\% level suggesting that independent directors enhance the monitoring of the board and reduce managerial discretion. We also find a negative relationship between leverage and earnings management suggesting that debt is an effective governance device to limit earnings management as argued by Jensen (1986). Table 3 shows that firm performance is negatively associated with discretionary accruals. This relationship is not consistent with the results of Kaznik (1999) and Haw et al. (2004).

Table 3. Panel Regression Of The Proportion Of Women On The Boardroom

\begin{tabular}{|c|c|c|c|c|c|c|}
\hline & \multicolumn{2}{|c|}{ DA1 } & \multicolumn{2}{|c|}{ DA2 } & \multicolumn{2}{|c|}{ DA3 } \\
\hline & Coef. & $t$ student & Coef. & t student & Coef. & t student \\
\hline Women & $-7.794 * *$ & -2.01 & $-9.884 * *$ & -2.1 & -1.049 & -1.61 \\
\hline WomChair & $-0.075^{* *}$ & -1.98 & -1.759 & -1.01 & -1.755 & -1.57 \\
\hline WomCEO & 2.163 & 0.79 & -0.149 & -0.5 & -0.145 & -0.3 \\
\hline WomCFO & -0.657 & -0.27 & -0.181 & -0.87 & -0.176 & -0.37 \\
\hline Indep & $-5.065 *$ & -1.91 & $-0.377 * *$ & -1.99 & 0.416 & 0.78 \\
\hline Duality & 0.733 & 0.61 & 0.256 & 1.42 & 0.265 & 1.02 \\
\hline Bsize & $-0.753 * * *$ & -2.83 & -0.068 & -1.05 & -0.070 & -1.59 \\
\hline FSize & $0.340 * *$ & 1.96 & $0.095 * * *$ & 2.61 & $0.098 * *$ & 2.24 \\
\hline Float & 4.856 & 1.04 & 0.501 & 1.63 & 0.490 & 0.83 \\
\hline ROA & $-0.574 * * *$ & -3.06 & -0.003 & -0.18 & -0.002 & -0.11 \\
\hline MBR & 0.030 & 0.47 & -0.002 & -0.36 & -0.008 & -0.31 \\
\hline Lev & $-0.021 *$ & -1.87 & 0.010 & 1.59 & 0.010 ** & 2.1 \\
\hline Constant & 1.573 & 0.35 & -0.116 & -0.21 & -0.094 & -0.17 \\
\hline $\mathbf{R}^{2}$ & \multirow{2}{*}{\multicolumn{2}{|c|}{$\begin{array}{c}0.318 \\
17.31 * * *\end{array}$}} & \multirow{2}{*}{\multicolumn{2}{|c|}{$\begin{array}{l}0.392 \\
205 * *\end{array}$}} & \multicolumn{2}{|c|}{0.185} \\
\hline Fisher & & & & & & \\
\hline
\end{tabular}


Table 4 shows that there is a negative and significant relationship between the presence of at least three women on the board and earnings management. This result suggests that the presence of more women on boards strengthens the control of the board as predicted by the critical mass theory. This finding supports the critical mass theory (Konrad and Kramer, 2006). As a governance mechanism, the number of women on the board can fill the same role as independent directors. These directors are also able to improve the efficiency of monitoring of the board as well as gender diversity. This finding suggests that by increasing the number of women on board through regulation and legislation, French firms are likely to enhance the effectiveness of the board to better detect earnings management.

These findings suggest that efforts undertaken by political bodies to promote equality between men and women on boards are beneficial for French-listed companies since the presence of more women on the boardroom is likely to limit earnings management. However, the mere imposition of a quota for women is not sufficient. The Norwegian Experience has indeed shown that the quota of women negatively affects firm performance (Ahern and Dittmar, 2012). The focus then should be on appointing women with qualifications and experience in management and as directors of the board.

Table 4. Panel Regression Of The Presence Of At Least Three Women On The Boardroom

\begin{tabular}{|c|c|c|c|c|c|c|}
\hline \multirow[b]{2}{*}{ Variable } & \multicolumn{2}{|c|}{ DA1 } & \multicolumn{2}{|c|}{ DA2 } & \multicolumn{2}{|c|}{ DA3 } \\
\hline & Coef & t student & Coef & t student & Coef & t student \\
\hline 3women & $-1.209 *$ & -1.83 & $-0.338 *$ & -1.8 & $-0.346^{*}$ & -1.86 \\
\hline WomChair & $-0.522 *$ & -1.72 & -1.752 & -1 & -1.748 & -0.57 \\
\hline WomCEO & 1.769 & 0.64 & -0.252 & -0.74 & -0.254 & -0.56 \\
\hline WomCFO & -0.198 & -0.78 & -0.242 & -1.03 & -0.239 & -0.5 \\
\hline Indep & 4.246 & 1.6 & -0.381 & -1.5 & 0.412 & 0.78 \\
\hline Duality & 0.637 & 0.53 & 0.256 & 1.42 & 0.260 & 1.02 \\
\hline Bsize & $-0.772 * * *$ & -2.87 & -0.056 & -1.04 & -0.058 & -1.33 \\
\hline FSize & $0.324 *$ & 1.91 & $0.091 * * *$ & 2.64 & $0.094 * *$ & 2.19 \\
\hline Float & 4.311 & 0.92 & $0.519^{*}$ & 1.79 & 0.517 & 0.88 \\
\hline ROA & $-0.575 * * *$ & -3.05 & -0.003 & -0.2 & -0.003 & -0.13 \\
\hline MBR & 0.026 & 0.4 & 0.001 & -0.22 & 0.004 & -0.48 \\
\hline Lev & $-0.021 *$ & -1.78 & $0.010 *$ & 1.88 & $0.010 * *$ & 2.08 \\
\hline Constant & 1.714 & 0.38 & -0.282 & -0.43 & -0.294 & -0.57 \\
\hline $\begin{array}{l}\mathbf{R}^{2} \\
\text { Fisher }\end{array}$ & \multicolumn{2}{|c|}{$\begin{array}{c}0.314 \\
16.98 * * *\end{array}$} & \multicolumn{2}{|c|}{$\begin{array}{l}0.389 \\
2.02 * *\end{array}$} & \multicolumn{2}{|c|}{$\begin{array}{l}0.0196 \\
2 * *\end{array}$} \\
\hline
\end{tabular}

\section{CONCLUSION}

The purpose of this paper is to study the relationship between gender diversity on the boardroom and in top management and earnings management by French-listed firms. Based on a sample of 170 firms over 4 years, we find that the proportion of women in the board standing as a director or a chair reduces earnings management. This finding suggests that women are effective in their monitoring role and are then considered as a crucial corporate governance device. As a chair, women may be inherently more likely to detect earnings manipulation to avoid litigation risk and loss of reputation as they do not easily access to such positions.

We also find that the relationship between the presence of at least three women on the board and earnings management is negative. This result is supported by the critical mass theory and suggests that by increasing the number of women on board through regulation and legislation, French firms are likely to enhance the effectiveness of the board to better detect earnings management. Hence, political actions are likely to reduce the influence of the $\mathrm{CEO}$ and top management over its composition. This reduction in the power of management to perpetuate the old boys' club mentality is compatible with the idea of women on boards being better "watchdogs" and then an effective corporate governance device.

These findings suggest that efforts made by political bodies to promote equality between men and women are beneficial for French-listed companies by limiting earnings management practices. We might expect better results from the participation of more women in the boardroom following the adoption of Zimmermann/Cope 
French law in 2011. This holds by appointing women with qualifications and experience in management and as directors of the board. However, regulating or imposing a quota of women on boards can create a temporal shortage of qualified women available to take up such positions. Future research should then focus on testing the longer term effects of improving balance on corporate boards.

\section{AUTHOR INFORMATION}

Faten Lakhal, PhD is a Professor in Accounting at the University of Sousse (Tunisia) and a fellow researcher at the Institut de Recherche en Gestion at Paris-Est University (France). Her major publications include Gender, Work, and Organization, the Review of Accounting and Finance, Bankers, Markets and Investors, Managerial Finance, The International Journal of Business, Managerial Auditing Journal, The International Journal of Managerial Finance among others. Her special research interests are in corporate governance, corporate disclosure, earnings quality and gender diversity. Email: lakhal@u-pec.fr (corresponding author).

Amal Aguir is a PhD student in Finance at the University of Sousse (Tunisia). Her special research interests are in corporate governance, earnings quality, gender diversity and CEO compensation.

Nadia Lakhal is a PhD student in Finance at the University of Sousse (Tunisia). Her major publications include the European Journal of Business and Management. Her special research interests are in corporate governance, corporate disclosure, earnings quality and gender diversity.

Adnane Malek, PhD is a Professor in Management at the University of Manouba (Tunisia). His major publications include a book chapter. His special research interests are in industrials relations, gender diversity and human resources management.

\section{REFERENCES}

Adams, R., Ferreira D. (2009). Women in the boardroom and their impact on governance and performance. Journal of Financial Economics, Vol. 94, pp. 291-309.

Ahern, K. R., Dittmar A. K. (2012). The changing of the boards: the impact on firm valuation of mandated female board representation. Quarterly Journal of Economics, 127(1) 137-197.

Barua, M. J., Tamuly and R.A., Ahmed. (2010). Mutiny or clear sailing? Examining the role of the Asian elephant as a flagship species. Human Dimensions of Wildlife, 15 (2) 145-160

Beasley, S. (1996). An Empirical Analysis of the Relation Between the Board Of Director Composition and Financial Statement Fraud. The Accounting Review, 70 (4) 443-466 Bebchuk L. and Jesse Fried, M. (2005). Pay Without Performance: Overview of the Issues. Journal of Applied Corporate Finance, Morgan Stanley, 17(4 ) 8-23.

Betz, M. O'Connell, L., Shephard, M. (1989). Gender differences in productivity for unethical behaviour. Journal of Business Ethics, Vol. 8, pp. 321-324.

Bozec, Y. (2008). Concentration de l'actionnariat, séparation des droits de vote et droits. Canadian Journal of Administrative Sciences.

Byrnes, J. P., Miller, W. D., Schafer, W. (1999). Gender differences in risk taking: a meta-analysis. Psychol. Bull, Vol. 125, pp. 367-383.

Carter, D.A., Simkins, B.J., Simpson, W.G. (2003). Corporate governance, board diversity, and firm value. The Financial Review, Vol. 38, pp. 33-53.

Catalyst, (2011). Increasing gender diversity on boards: Current index of formal approaches.

Campbell, K. and Minguez-Vera, A. (2008). Gender diversity in the boardroom and firm financial performance. Journal of Business Ethics, Vol. 83, pp. 435-51.

Chen, L.T.W., Chan, R.Y.K and Leung, T.Y. (2010). Management demography and corporate performance: Evidence from China. International Business Review, 19(3), 261-275.

Chen, X., Chung Q. (2002).Abnormal accruals-based anomaly and manager's motivations to record abnormal accruals, working paper.

Dallas, L. L., (2002). The New Managerialism and Diversity on Corporate Boards of Directors. Public Law and 
Legal Theory Working Paper 38 (Spring), University of San Diego School of Law.

Daily, C., Certo, S., Dalton, D. (1999). A decade of corporate women: Some progress in the boardroom, none in the executive suite. Strategic Management Journal, Vol. 20 pp. 93-99.

Dechow, R., Sloan, R., Sweeney, A. (1995). Detecting Earnings Management. The Accounting Review, 70 (2) 19932025.

Dechow, P., Sloan, R., Sweeney, A. (1996). Causes and Consequences of Earning Manipulations: An Analysis of Firm Subject to Enforcement Actions by the SEC. Contemporary Accounting Research, 13(1) 1-136.

DuCharme, L. L., Malatesta, P.H., S. E. Sefcik. (2004). Earnings management, stock issues, and shareholder lawsuits. Journal of Financial Economics, 71, pp. 27-49.

Duchin, R., J.G. Matsusaka, and O Ozbas. (2010). When are outside directors effective? Journal of Financial Economics, Vol. 96, pp. 195-214.

Farrell, K.A., Hersch P.L., (2005). Additions to Corporate Boards: The effect of Gender. Journal of Corporate Finance, No. 1-2, pp. 85-106.

Firth, M., Fung P. M. P., Rui O. M. (2007). Ownership, two-tier board structure, and the informativeness of earnings-Evidence from China. Journal of Accounting and Public Policy, Vol. 26, pp. 463-496.

Fondas, N., Sassalos S. (2000). A different voice in the boardroom: how the presence of women directors affects board influence over management. Global Focus, Vol. 12, pp. 13-22.

Ford, R. C., Richardson W. D. (1994). Ethical decision making: a review of the empirical literature. Journal of Business Ethics, 13(3) 205-221

Granovetter, M. (1978). Threshold models of collective behaviour. American Journal of Sociology, Vol. 83, pp. $1420-1443$

Gul, F.A., Srinidhi, B., Tsui, J. (2011). Female Directors and Earnings Quality. Journal of Contemporary Accounting Research, 28(5) 1610-1643

Haw, I., S Ho, and Yuansha, L. (2011). Corporate governance and earnings management by classification shifting. Contemporary Accounting Research, 28(2) 517- 553.

Healy. P., Wahlen, J. (1999). A Review of the Earnings Management Literature and its Implications for Standard Setting. Accounting Horizons, 13(4) 365-384.

Hunton, J.E., Libby, R., Mazza, C.L. (2006). Financial reporting transparency and earnings management. The Accounting Review, 81(1) 135-157.

Huse, M., and Solberg A. G., (2006). Gender-related boardroom dynamics. How Scandinavian women make and can make contributions on corporate boards. Women in Management Review, 21(2) 113-130.

Jeanjean, T. (2000). Corporate Governance and Earnings Management. $24^{\text {th }}$ congres of the European Accounting Association, Price Waterhouse Coopers Doctoral Cooloquium, pp. 18-23.

Jensen, M. C., Meckling W., (1976). Theory of the firm: managerial behaviour agency costs and ownership structure. Journal of Financial Economics, Vol. 3, pp. 305-360.

Jensen, M.C., (1986). Agency Costs of Free Cash Flow Corporate Finance and Takeovers. American Economic Review, Vol. 76, pp. 323-329

Jiang, J., Petroni K., Wang We. (2010). CFOs and CEOs: Who have the most influence on earnings management? Journal of Financial Economics, Vol. 96, pp.513-526.

Kasznik, Barth and Mary. (1999). Share Repurchases and Intangible Assets. Journal of Accounting and Economic, 28(2) 211-241.

Klenke, K. (2003). Gender influences in decision-making processes in top management teams. Management Decision, 41(10) 1024-1034.

Kothari, S. P., Andrew J. L., Wasley C.E. (2005). Performance Matched Discretionary Accrual Measures. Journal of Accounting and Economies, Vol. 39, pp. 163-197.

Kramer, V., Konrad A., Erkut S. (2006). Critical mass on corporate boards: why three or more women enhance governance. Wellesley Centres for women, Report in. WCW11, Wellesley, MA: Wellesley Centers for women.

Konrad, A., Kramer, V., Erkut S. (2008). Critical Mass: The Impact of Three or More Women on Corporate Boards. Organizational Dynamics, 37(2) 145-164.

Krishnan, G., Parsons L. (2008). Getting to the Bottom Line: An Exploration of Gender and Earnings Quality. Journal of Business Ethics, 78(1) 65-76.

Luckerath-Rovers, M. (2010). Women on Boards and Firm Performance. Journal of management and gouvernance, pp.1-19 
McKinsey and Company, (2007). Women Matter: Gender Diversity. A Corporate Performance Driver Note that although the analysis did not show a causal link, this research clearly argues for greater gender diversity among corporate leaders.

Merridee, L. Bujaki, Bruce J. McConomy. (2010). Gendered interactions in corporate annual report photographs. Gender in Management: An International Journal, 25(2) 119 - 136

Nielsen, S. T., Huse M. (2010). Women Directors' Contribution to Board Decision-making and Strategic Involvement: the Role of Equality Perception. Corporate Governance: an International Review, 17(3) 320337.

Peasnell, K.V., Pope P.F., Young S. (2000). Accrual management to meet earnings targets UK evidence pre and post Cadbury. British Accounting Review, Vol. 32, pp. 415-445

Peni, Emilia, (2011). Female executives, chairwomen, and corporate governance. Proceedings of the 47th Annual Meeting of the Eastern Finance Association.

Peni E., Vahamaa S. (2010). Female executive and earnings management, Managerial Finance, 36(7) 629-645.

Powell, Ansic, M. D. (1997). Gender differences in risk behaviour in financial decision making: An experimental analysis. Journal of Economic Psychology, 18(6) 605-627.

Raman, K., Shahrur, H. (2008). Relationship-specific investments and earnings management: Evidence on corporate suppliers and customers. The Accounting Review, 83(7) 1041-1081.

Rose, C. (2007). Does female board representation influence firm performance? The Danish evidence.Corporate Governance, 15(2) 404-413.

Roychowdhury, S. (2006). Earnings management through real activities manipulation. Journal of Accounting and Economics, Vol. 42, pp. 335-370.

Ruigrok, W., Peck, S., and Tacheva, S. (2007). Nationality and gender diversity on Swiss corporate boards. Corporate Governance: An International Review, 15(4) 546-557.

Schipper K., (1989), Commentary on Earnings Management. Accounting Horizons, 3(4) 91-102

Schminke, M., Wells D., Peyrefitte J, T. C. Sebora T.C. (2002). Leadership and Ethics in Work Groups: A Longitudinal Assessment. Group and Organization Management, Vol. 27, pp.272-294.

Valenti A. (2008). The Sarbanes-Oxley Act of 2002: Has It Brought About Changes in the Boards of Large U. S. Corporations? Journal of Business Ethics, 81(2) 401-412.

Yang, T., Linck J., Netter J. (2008). The determinants of board structure. Journal of Financial Economics, Vol.87, pp. 308-28.

Ye, K., Zhang, R., Rezaee, Z. (2010). Does top executive gender diversity affect earning quality? A large sample analysis of Chinese listed firms. Advances in Accounting, incorporating Advances in International Accounting, 6(1) 47-54.

Zuobao, W., Xie, W., (2010). Do Women Directors Improve Firm Performance in China? Journal of Corporate Finance, Vol.10, pp. 409-430 